https://doi.org/10.4314/rjeste.v3i2.4

\title{
Performance Assessment of Erosion Remediation Measures and Proposal of The Best Management Practices for Erosion Control in Sebeya Catchment, Rwanda
}

\author{
Félicien Majoro ${ }^{1}$, Umaru Garba Wali ${ }^{1}$, Omar Munyaneza ${ }^{1}$, François-Xavier Naramabuye ${ }^{2}$ and Concilie \\ Mukamwambali $^{3}$ \\ ${ }^{1}$ University of Rwanda, College of Science and Technology, Department of Civil, Environmental and Geomatics Engineering, \\ P.O. Box 3900, Kigali, Rwanda \\ ${ }^{2}$ University of Rwanda, College of Agriculture Science and Veterinary Medicine, P.O. Box 3971, Kigali, Rwanda \\ ${ }^{3}$ University of Rwanda, College of Education, Department of Mathematics, Science and Physical Education, P.O. Box 55, \\ Rwamagana, Rwanda
}

*Corresponding author: Félicien Majoro, majoro.felicien@ yahoo.fr

\begin{abstract}
Soil erosion is an environmental concern that affects agriculture, wildlife and water bodies. Soil erosion can be avoided by maintaining a protective cover on the soil to create a barrier to the erosive agent or by modifying the landscape to control runoff amounts and rates. This research is focused on Sebeya catchment located in the Western Province of Rwanda. Sebeya catchment is one of the most affected areas by soil erosion hazards causing loss of crops due to the destruction of agricultural plots or riverbanks, river sedimentation and damages to the existing water treatment and hydropower plants in the downstream part of the river. The aims of this research were to assess the performance of erosion remediation measures and to propose the Best Management Practices (BMPs) for erosion control in Sebeya catchment. Using literature review, site visits, questionnaire and interviews, various erosion control measures were analyzed in terms of performance and suitability. Land slope and soil depth maps were generated using ArcGIS software. The interview results indicated that among the 22 existing soil erosion control measures, about $4.57 \%$ of farmers confirmed their existence while $95.43 \%$ expressed the need of their implementation in Sebeya catchment. Furthermore, economic constraints were found to be the main limitative factors against the implementation of soil erosion control measures in Sebeya catchment. Also, the majority of farmers suggest trainings and mobilization of a specialized technical team to assist them in implementing soil conservation measures and to generalize the application of fertilizers in the whole catchment. Finally, soil erosion control measures including agro-forestry, terraces, mulching, tree planting, contour bunds, vegetative measures for slopes and buffer zones, check dams, riverbanks stabilization were proposed and recommended to be implemented in Sebeya catchment.
\end{abstract}

Keywords: Erosion control measures, Sebeya catchment, Rwanda

\section{INTRODUCTION}

Soil erosion is an environmental hazard that affects all landforms. Its causes and effects should be studied in order to control it. In Europe, suitable soil erosion control measures have been developed to improve agricultural productivity (Bakker et al., 2007). Approximately U.S.\$37.9 million in the United States and \$41.2 million in North America were used in soil erosion control per annum (Christoffel et al., 2000). 
Agricultural land of developing countries is prone to erosion effects because of poor farming techniques and lack of financial means for their farming systems to replace lost soils and nutrients. Also, sediment control requires high costs (Ouyang et al., 2005).

It is reported that soil erosion is the major cause of land degradation with serious impacts on agricultural productivity (Bakoji, 2017). Human activities were blamed to cause storm runoff and accelerate soil erosion (Ampofo et al., 2002). An essential part of soil and water conservation is to control soil erosion, particularly through comprehensive land and water management techniques and to develop methods and techniques for mitigating harmful effects of soil loss and sediment movement (Shahin, 1993).

Recently, water quality was monitored by Rwanda Water and Forest Authority (RWFA) at the outlet of Sebeya river flowing into Lake Kivu. The measurements and findings showed that there are: Excessive sediment loads and turbidity due to mining and agriculture activities, high loads of e. coli and coliform bacteria from untreated sewage, high organic loads with high biochemical oxygen demands (BOD) and chemical oxygen demands (COD) resulting to low concentrations of oxygen. Recorded turbidity and Total Suspended Solids (TSS) values were 1102 NTU and $4414.5 \mathrm{mg} / \mathrm{L}$ respectively (IWRM, 2018). All turbidity values recorded were very high compared with World Health Organization (WHO) and Rwanda Standard Board (RSB) drinking water standards of 5-25 NTU (WHO, 2011).

Explicitly, water quality degradation is a challenge in this catchment. The current sedimentation in Sebeya river impacts on hydropower and water treatment plants (Munyaneza et al., 2015). Recently, the study conducted by Rwanda Ministry of Environment highlighted a very high risk of erosion in the North-Western part of Rwanda, covering areas of Sebeya Catchment (MoE, 2018a; Karamage et al., 2016). However, there is no specific research on how T-value (allowable soil loss tolerance) can be reached by means of soil erosion remediation measures in Sebeya catchment.

The objectives of the present study were: (1) to assess the actual status of soil erosion control in Sebeya catchment; (2) to assess the performance and the suitability of various soil erosion control measures in Sebeya catchment; (3) to propose suitable and best management practices for erosion control in Sebeya catchment.

Literature review, site visits, questionnaire and interviews were used to get sufficient information on the existing soil erosion control measures, their performance and suitability within Sebeya catchment. This research shows high necessity of improving soil erosion control practices. A combination of soil erosion control measures including: Agronomic measures, terraces, contour bunds, contour tillage and check dam has been found to be the most effective in reducing soil erosion in Sebeya catchment. 


\section{METHODOLOGY}

\subsection{Study Area}

The study area of this research is focused on Sebeya catchment located in the Western Province of Rwanda and shared by four administrative units namely Rubavu, Nyabihu, Rutsiro and Ngororero Districts (figure1).

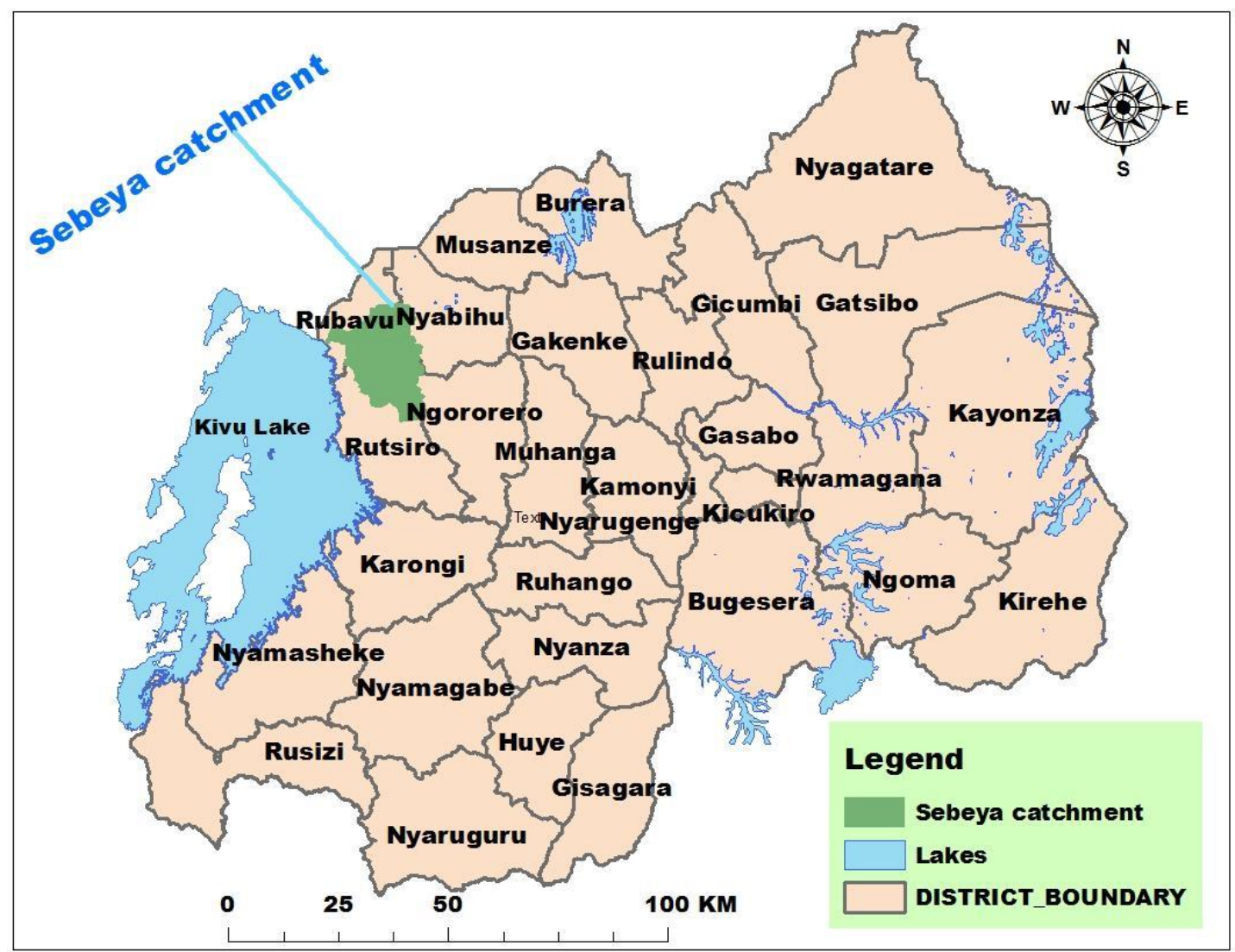

Figure 1. Location of Sebeya catchment on Rwanda map

The total surface area of Sebeya catchment represents $1.38 \%$ of the total surface area of Rwanda $\left(26,338 \mathrm{~km}^{2}\right.$ including water bodies), which totalizes $363.1 \mathrm{~km}^{2}$. The population density in Sebeya catchment is $644 \mathrm{hab} / \mathrm{km}^{2}$ while the average population density of Rwanda is about $415 \mathrm{hab} / \mathrm{km}^{2}$. This high demographic pressure is one of the indirect factors accelerating soil erosion in Sebeya catchment (NISR, 2014). The soil in this catchment favors agriculture due to its high infiltration rates and its high minerals content. Located in the high elevation region of the country with altitude varying between $1,462 \mathrm{~m}$ to $2,979 \mathrm{~m}$ a.b.s.l. (meters above sea level), this catchment is also characterised by steep slopes and abundant rainfall varying between 1,200 $\mathrm{mm}$ to $1,700 \mathrm{~mm}$ per year (IWRM, 2018). 


\subsection{Data Collection}

Literature review, site visits, questionnaire and interviews were used to get sufficient information on the existing soil erosion control measures, their performance and suitability within Sebeya catchment.

\subsubsection{Literature review}

The information related to the current situation of soil erosion rates and soil erosion control in Sebeya catchment have been obtained from published journal articles and different reports of government bodies. Comparatively and from literature review, a number of individual and combinations of conservation practices showed high percentages of soil loss reduction when applied in agricultural fields. This research was intended to recommend these BMPs of high performance for their adoption and implementation in Sebeya catchment.

\subsubsection{Site visits}

During the study period, different site visits were frequently conducted to get primary data on main features of the site: land use and land cover, site topography, hydrographic network, soil characteristics and about the existing soil erosion control measures in Sebeya catchment.

\subsubsection{Questionnaire and interview}

The above figure 1 shows that Sebeya catchment extends on many sectors of 4 Districts while the table 1 below shows that the overlapped area between Rubavu and Sebeya catchment is the largest and equal to 44.6\%. The next largest overlapped area comes to be $41.3 \%$ between Rutsiro and Sebeya catchment.

Table 1. Overlap between Districts and Sebeya catchment (RNRA, 2012)

\begin{tabular}{|c|c|c|c|c|c|c|}
\hline \multicolumn{2}{|c|}{ Catchment } & \multicolumn{2}{|c|}{ Area of each District } & \multicolumn{3}{|c|}{ Overlap between District \& Catchment } \\
\hline Name & Area km² & District & Area km² & Area km² & $\%$ Catchment & $\%$ District \\
\hline \multirow{5}{*}{$\begin{array}{l}\text { Sebeya } \\
\text { catchment }\end{array}$} & \multirow[t]{5}{*}{363} & Ngororero & 679 & 37 & $11 \%$ & $5 \%$ \\
\hline & & Rutsiro & 1,157 & 139 & $41.3 \%$ & $12 \%$ \\
\hline & & Nyabihu & 532 & 38 & $11.3 \%$ & $7 \%$ \\
\hline & & Rubavu & 388 & 150 & $44.6 \%$ & $39 \%$ \\
\hline & & Total & & 363 & $100 \%$ & \\
\hline
\end{tabular}

Following to this fact, the sampled sectors for farmers' interview in Sebeya catchment has been limited to these 2 Districts of large overlapped areas. The table 2 below shows the sampled sectors and the number of farmers interviewed in each sector. 
https://doi.org/10.4314/rjeste.v3i2.4

Table 2. Selection of sectors for farmers' interview in Sebeya catchment

\begin{tabular}{|c|c|l|c|}
\hline SN & District & Sector & Number of interviewees \\
\hline 1 & & Gisenyi & 12 \\
\cline { 4 - 4 } 2 & \multirow{3}{*}{ Rubavu } & Rugerero & 14 \\
\cline { 4 - 4 } & Nyundo & 15 \\
\cline { 4 - 4 } & & Nyakiriba & 4 \\
\cline { 3 - 4 } 5 & Kanama & 15 \\
\hline 6 & Rutsiro & Nyabirasi & 15 \\
\hline \multicolumn{3}{|c|}{ TOTAL } & 75 \\
\hline
\end{tabular}

Questionnaire is one of the methods used to find information related to this study. Structured interviews were conducted at the site to get constructive views from 75 farmers on the current status of soil erosion rates and the implementation of its control measures in Sebeya catchment. Microsoft Excel was used to analyze data in terms of tables and graphs.

\subsubsection{Secondary data collection}

DEM data have been collected from Center of Geographical Information System (CGIS Rwanda) for delineation and slope analysis of Sebeya catchment. Also, a soil data shapefile has been used to assess the soil depth within the catchment.

\section{RESULTS AND DISCUSSIONS}

\subsection{Risk of Soil Erosion in Sebeya Catchment}

Soil erosion within Sebeya catchment was categorized into 6 classes such as 0-5 very low, 5-10 low, 1025 moderate, 25-50 high, 50-100 very high and greater than 100 extremely high in tons/ha/year where around 8000 ha are under high risk, around 6000 ha under very high risk while around 4000 ha are under extremely high risk of soil erosion (MoE, 2018b). In Sebeya catchment, the high risk of soil erosion results from improper management of land, heavy rainfall and human activities that disturb the soil.

\subsection{On-Site and Off-Site Effects of Soil Erosion in Sebeya Catchment}

Soil erosion is a common issue in land degradation where it can impact both on site and off site. Soil erosion is causing loss of soil nutrients (nitrogen, phosphorus, potassium, calcium, etc.) and decrease of water holding capacity which ultimately decline land productivity. Sediment in rivers is composed mainly by eroded soil and associated pollutants from agriculture, mining, and grazing activities. Keya, Gihira and Gisenyi hydropower plants which use water from Sebeya river are facing technical issues due to sediments generated by soil erosion (Munyaneza et al., 2015). Also, Gihira water treatment plant and Lake Kivu are affected by the problem of pollution caused by runoff which collects pollutant from different parts of catchment such as oil, pesticides, sediments, bacteria, and other chemicals deposited into Sebeya river (IWRM, 2018). 


\subsection{Existing Soil Erosion Control Measures in Sebeya Catchment}

The interview results in table 3 indicate that among the 22 listed erosion control measures, about $4.57 \%$ of farmers confirmed their existence while $95.43 \%$ expressed the need of their implementation in Sebeya catchment. Also, it is reported that various soil erosion control measures including trees planting, agro-forestry and terraces have been applied to rehabilitate 1,373 hectares in Sebeya catchment (IWRM, 2017). This means that there is a need of improvement of soil conservation measures in Sebeya catchment. Soft BMPs are those measures that are implemented easily with low cost including: mulching, cover crops and vegetation, trees planting, protective grasses on river banks, no tillage method and buffer zones. Existing hard BMPs in Sebeya catchment are mainly terraces and anti-erosive ditches. Radical terraces and progressive terraces are still few; they were implemented to reduce the impact of topographic factor that influences soil erosion in this catchment (IWRM, 2016).

\subsection{Improvement Needed in Implementing Soil Erosion Control Measures in Sebeya Catchment}

Adding the number of voices from farmers who need improvement and the number of voices which don't need improvement on the existing soil erosion measures, the following steps describe the computations in the table3. Let's Xn be the percentage of farmers who need the implementation of a soil erosion remedial measure and $\mathrm{Xp}$ the percentage of farmers confirming the existence of a soil erosion control measure in Sebeya catchment. Then $\mathrm{Xn}-\mathrm{Xp}=\mathrm{NG}$ is the Needed Gap. As a result, IN will be Improvement Needed if $N G>0$ while INN will be Improvement Not Needed if $N G \leq 0$. The data in the table3 revealed that the Needed Gap (NG) values for all the 22 items of 6 categories ranged from 4.76 up to 2.86 and were all positive. This indicated that farmers needed improvement in all the 22 cultural practices in soil erosion prevention and control in Sebeya catchment. The results of the study showed that farmers of Sebeya catchment need improvement on various BMPs of erosion control (in agricultural fields, for slope and river bank stabilization, for sediments control and in reducing the velocity and volume of Sebeya river and its tributaries).

In absence of BMPs, soil erosion rates continue to increase. That's why improvement on soil erosion control will be always needed because reaching T-value (allowable soil loss tolerance rate) seems to be an idealization. A similar study in Nigeria revealed that farmers needed improvement in all the existing soil erosion control measures in Kogi state (Onu \& Mohammed, 2014).

Table 3. Improvement needed in the implementation of BMPs in Sebeya catchment

\begin{tabular}{|c|c|c|c|c|c|c|c|}
\hline $\begin{array}{l}\mathbf{S} \\
\mathbf{N}\end{array}$ & Measures ca & gory & BMP & $\operatorname{Xn}(\%)$ & Xp(\% & $\begin{array}{l}(X n-X p) \% \\
=N G\end{array}$ & $\begin{array}{l}\text { Remar } \\
\mathbf{k}\end{array}$ \\
\hline \multirow[t]{4}{*}{$\mathbf{1}$} & \multirow{4}{*}{$\begin{array}{l}\text { In } \\
\text { agriculture } \\
\text { field }\end{array}$} & Mul & & 4.13 & 0.63 & 3.49 & IN \\
\hline & & Terr & & 4.63 & 0.13 & 4.51 & IN \\
\hline & & Anti & osive ditches & 4.76 & 0.00 & 4.76 & IN \\
\hline & & Con & bunds & 4.44 & 0.32 & 4.13 & IN \\
\hline \multirow[t]{2}{*}{2} & \multirow{2}{*}{$\begin{array}{l}\text { For slope } \\
\text { stabilization }\end{array}$} & Tree & & 4.76 & 0.00 & 4.76 & IN \\
\hline & & Veti & grass planting & 4.19 & 0.57 & 3.62 & IN \\
\hline
\end{tabular}




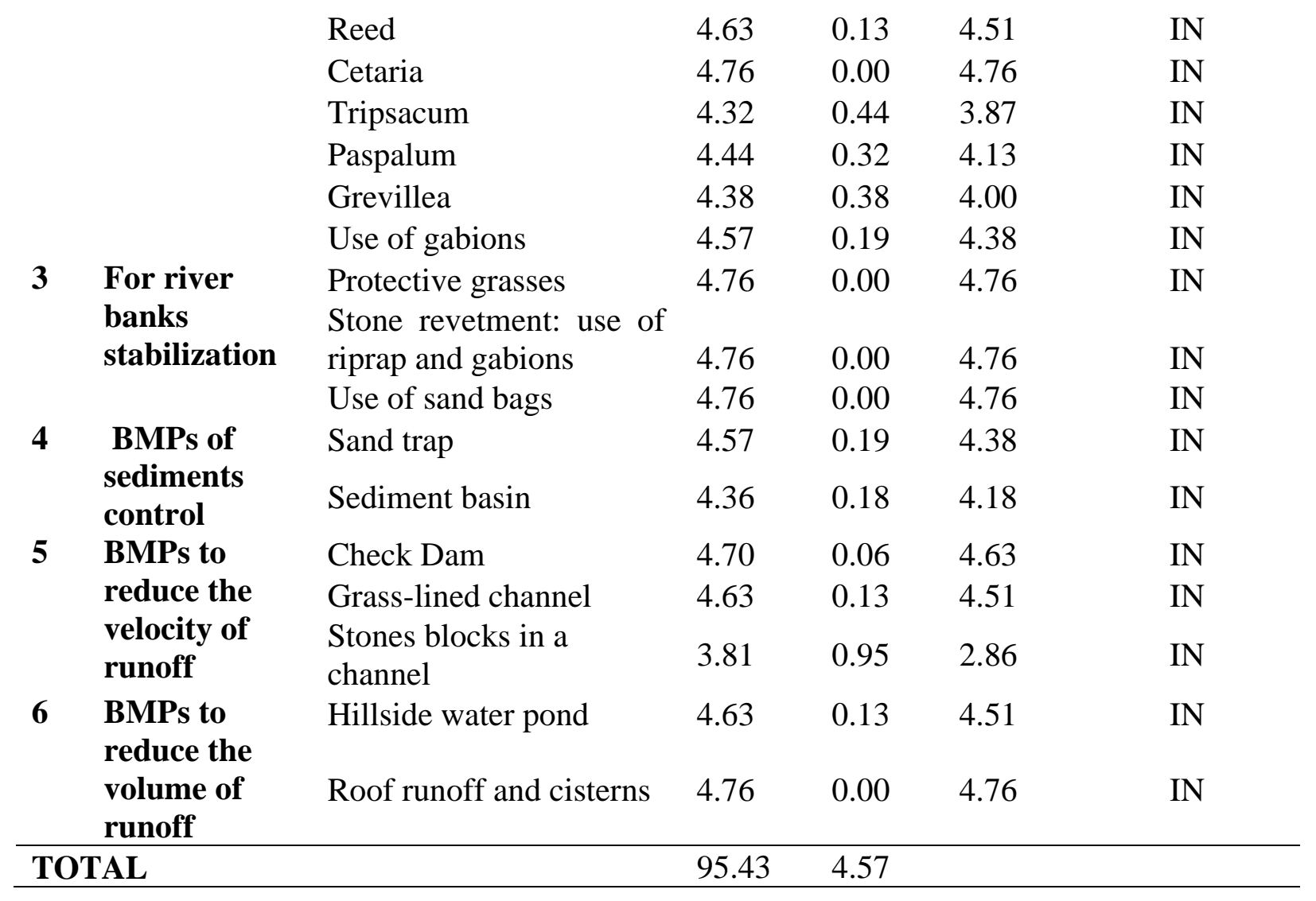

\subsection{Performance Assessment of Various Erosion Control Measures}

From literature review, various conservation practices showed high percentages of soil loss reduction when applied in agricultural fields (table4 and table5).

\section{Table 4. Performance of various hard BMPs}

\begin{tabular}{|l|l|l|}
\hline$N^{\mathbf{0}}$ & Structure & \multicolumn{1}{|c|}{ Description and performance of soil erosion control measures } \\
\hline 1 & $\begin{array}{l}\text { Check } \\
\text { Dam }\end{array}$ & $\begin{array}{l}\text { The major function of check dams is to lessen water velocity and to catch } \\
\text { sediments in gullies with performance about 41.5\% (Gray \& Leiser, 1982). }\end{array}$ \\
\hline 2 & Terraces & $\begin{array}{l}\text { Terraces are earth embankments constructed across the slope to intercept } \\
\text { surface runoff. Terraces are more favorable in agricultural land with steep } \\
\text { slopes ranging from 16\% to 40\% with high erodibility factor (IWRM, } \\
\text { 2016). It is shown that terracing reduces soil erosion up to 99\% (Bai et al., } \\
\text { 2019). }\end{array}$ \\
\hline 3 & $\begin{array}{l}\text { Contour } \\
\text { bunds }\end{array}$ & $\begin{array}{l}\text { These are constructed along the contours, low rainfall areas (less than 600 } \\
\text { mm/year), soil depth > 20 cm, slope < 7 \%, good infiltration capacity, built } \\
\text { in series to divide the length of the slope. In the areas of contours bunds } \\
\text { applications, gullies were reduced at a very high rate of 72\% (Birhanu et } \\
\text { al., 2014). }\end{array}$ \\
\hline
\end{tabular}




\begin{tabular}{|l|l|l|}
\hline 4 & $\begin{array}{l}\text { Contour } \\
\text { tillage }\end{array}$ & $\begin{array}{l}\text { This is the simplest soil erosion control measure on sloping land, which } \\
\text { concurrently reduces runoff and increase water infiltration compared to } \\
\text { that which occurs in cultivation parallel to slope. The performance of } \\
\text { contour tillage in reducing soil erosion is ranged between 67-75\% (Liu et } \\
\text { al., 2010). }\end{array}$ \\
\hline 5 & $\begin{array}{l}\text { Sediment } \\
\text { basin }\end{array}$ & $\begin{array}{l}\text { The main function of sediment basins is to prevent sediment transport and } \\
\text { reduce sediment delivery. The efficiency of sediment basin to control soil } \\
\text { erosion is 30\% (Peng et al., 2011). These basins may also be used to } \\
\text { control the volume and velocity of the runoff through a timely release by } \\
\text { utilizing multiple spillways. }\end{array}$ \\
\hline 6 & $\begin{array}{l}\text { RWH } \\
\text { Ponds }\end{array}$ & $\begin{array}{l}\text { Hillside Rainwater Harvesting (RWH) Ponds are most efficient techniques } \\
\text { which controls soil erosion by reducing run off velocity and sediment } \\
\text { transport with efficiency varying between 99\% to 76\% (Barsher et al., } \\
\text { 2016). }\end{array}$ \\
\hline
\end{tabular}

Table 5. Performances of various soft BMPs

\begin{tabular}{|l|l|l|}
\hline $\mathbf{N}^{\mathbf{0}}$ & $\begin{array}{l}\text { Conservatio } \\
\text { n practices }\end{array}$ & \multicolumn{1}{|c|}{ Description and performance of soil erosion control measures } \\
\hline 1 & Mulching & $\begin{array}{l}\text { Mulching is one of the most efficient techniques of soil erosion control } \\
\text { where it influences C factor in reducing soil erosion (IWRM, 2016). } \\
\text { When mulching is applied using straw cover at slopes ranging from 15\% } \\
\text { to 25\%, its performance varies from 90\% to 60\% in a period of six } \\
\text { month (Dooley et al., 2005). }\end{array}$ \\
\hline 2 & $\begin{array}{l}\text { Protective } \\
\text { grasses on } \\
\text { river banks }\end{array}$ & $\begin{array}{l}\text { The major benefits of grasses in soil erosion control are: to intercept } \\
\text { rain, bind soil particles, trap sediment, reduce energy of runoff and to } \\
\text { enhance water infiltration. By their roots, grasses provided 80\% to 85\% } \\
\text { of the force that resisted slope failure and reduced runoff at 90\% } \\
\text { (Admiraal, 2007). }\end{array}$ \\
\hline 3 & $\begin{array}{l}\text { Tree } \\
\text { planting }\end{array}$ & $\begin{array}{l}\text { Trees plantation is one of the best management practices used to control } \\
\text { erosion. Canopy of trees intercepts rain drops, binds soil particles and } \\
\text { reduces runoff by enhancing infiltration. In a region covered by canopy } \\
\text { trees, erosion has been reduced at a rate of 95\% (Young, 1989). }\end{array}$ \\
\hline 4 & $\begin{array}{l}\text { Grassed } \\
\text { waterways }\end{array}$ & $\begin{array}{l}\text { Grassed waterways are effective conservation practices used to prevent } \\
\text { gullies formation along natural drainage ways. It has been found that } \\
\text { grassed waterways combined with terraces reduced runoff by 86\% and } \\
\text { soil erosion by 95\% (Gali et al., 2015). }\end{array}$ \\
\hline 5 & $\begin{array}{l}\text { No tillage } \\
\text { method }\end{array}$ & $\begin{array}{l}\text { No tillage method is one of the best land management techniques used to } \\
\text { manage soil structure, organic matter and to reduce soil erodibility and } \\
\text { erosion. No tillage technique reduces soil loss by 26-52\% (Barsher et } \\
\text { al., 2016). }\end{array}$ \\
\hline
\end{tabular}




\subsection{Suitability and Proposal of BMPs for Soil Erosion Control in Sebeya Catchment}

\subsubsection{Average slope of Sebeya catchment}

Generally, Sebeya catchment is characterized by high steep slopes which accelerate the rate of soil erosion (IWRM, 2018). Slope steepness is one of the important factors influencing soil erosion. Greater the slope more is the erosion. Based on the classification proposed by the Ministry of Environment (MoE) of Rwanda in 2018a, the level of soil erosion in Sebeya catchment can be grouped into 5 classes: Areas of very low risk of erosion have the slope varying 0-6\%; Areas of low risk of erosion have the slope varying between 6-16\%; Areas of medium risk of erosion have the slope varying between 16-40\%; Areas of high risk of erosion have the slope varying between $40-60 \%$ and areas of very high risk of erosion have the slope $>60 \%$. In order to get more information on slope ranges with associated covered areas, DEM data collected from Center of Geographical Information System (CGIS Rwanda) have been used to generate the slope map for slope analysis of Sebeya catchment (figure2). Following to this classification, the table 6 shows that 16-40\% represents the slope range comprising the largest portion of Sebeya catchment (55.8\%) and the average slope in Sebeya catchment has been estimated to $24.137 \%$.

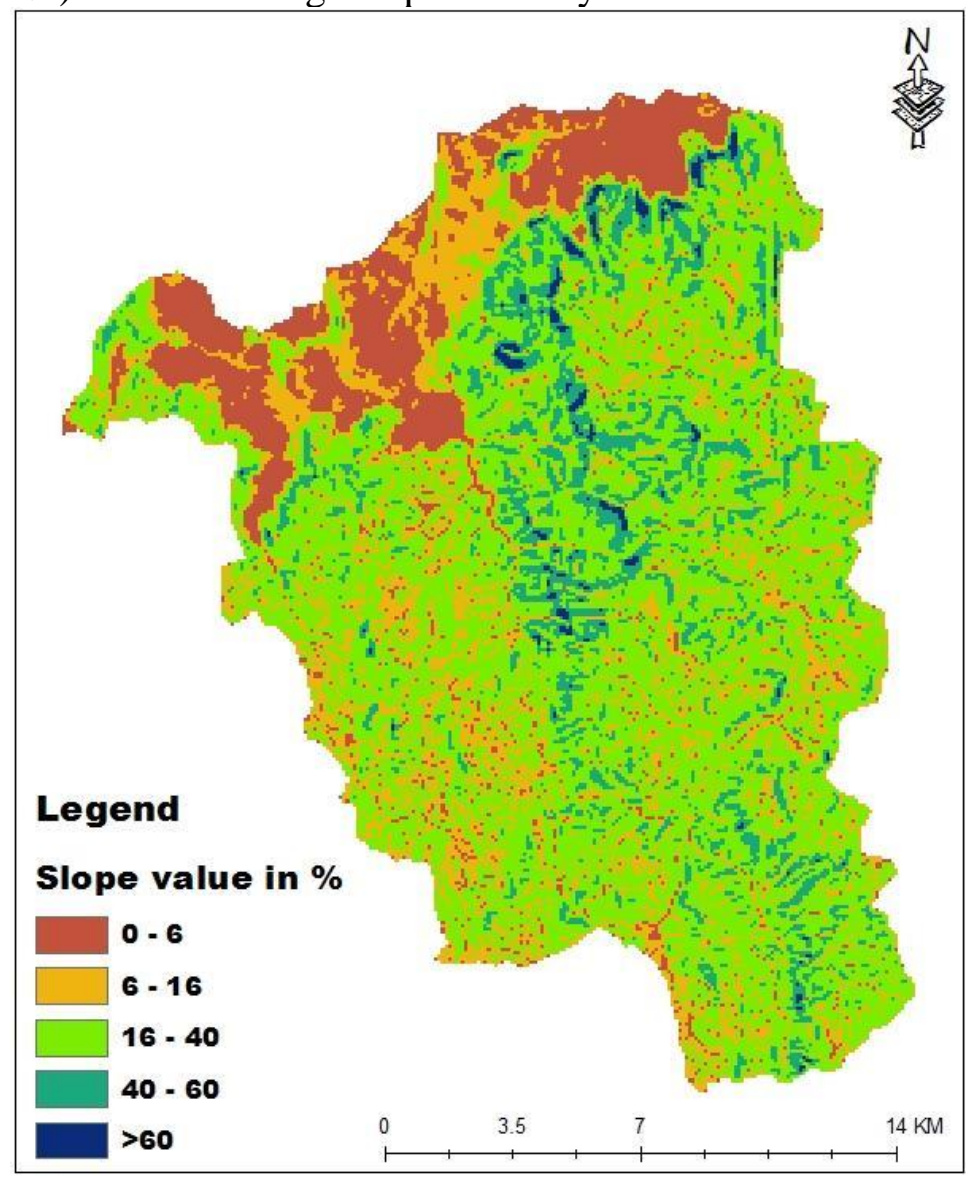

Figure 2. Sebeya catchment slope map 
Table 6. Calculation of average slope of Sebeya catchment

\begin{tabular}{|l|l|l|l|l|}
\hline $\begin{array}{l}\text { Slope } \\
\text { Classes } \\
(\%)\end{array}$ & $\begin{array}{l}\text { Area } \\
\text { covered } \\
\text { (ha) }\end{array}$ & $\begin{array}{l}\text { \% of } \\
\text { covered } \\
\text { area }\end{array}$ & $\begin{array}{l}\text { Average slope } \\
\text { Si }(\%)\end{array}$ & $\begin{array}{l}\text { Weighted slopes: } \\
\text { Ai*Si (ha) }\end{array}$ \\
\hline $0--6$ & 4620.871 & 12.72 & 3 & 13862.612 \\
\hline $6--16$ & 7292.557 & 20.08 & 11 & 80218.126 \\
\hline $16--40$ & 20271.042 & 55.8 & 28 & 567589.181 \\
\hline $40--60$ & 3819.932 & 10.51 & 50 & 190996.581 \\
\hline $60--90$ & 322.08 & 0.89 & 75 & 24155.998 \\
\hline Total & 36326.481 & 100 & $\begin{array}{l}\text { Weighted average } \\
=\mathbf{2 4 . 1 3 7}\end{array}$ & 876822.498 \\
\hline
\end{tabular}

\subsubsection{Soil depth and crops to be grown in Sebeya catchment}

The soil depth from which a growing crop can easily extract most of water needed may be shallow or deep. That's why it is imperative to proceed for a careful analysis of crops to be grown with their rooting depths and the available soil depths (IWRM, 2016).

The table7 shows an indicative list of main crops growing in Sebeya catchment with their rooting depths as experienced by many researchers. For more details with other crops to be grown in Sebeya catchment, the soil data shape file has been used to assess soil depth within the catchment (figure3).

Table 7. Crops grown in Sebeya catchment

\begin{tabular}{|l|l|c|l|}
\hline SN & List of crops & \multicolumn{2}{|c|}{ Rooting depth (cm) } \\
\hline 1 & Tea plantation & $0-50$ & (Sadeeka et al, 2019) \\
\hline 2 & Beans & $0-30$ & (FAO, 1983) \\
\hline 3 & Banana plantation & $0-20$ & (FAO, 1983) \\
\hline 4 & Maize & $0-10$ & (Plessis, 2003) \\
\hline 5 & Irish potatoes & $0-20$ & (Nedunchezhiyan et al, 2012) \\
\hline 6 & Soybeans & $0-30$ & (FAO, 1983) \\
\hline 7 & Groundnut & $0-35$ & (FAO, 1983) \\
\hline 8 & Cassava & $0-80$ & (FAO, 1983) \\
\hline 9 & Sugar cane & $0-20$ & (FAO, 1983) \\
\hline 10 & Rice & $0-40$ & (FAO, 1983) \\
\hline 11 & Carrots & $0-45$ & (Lott \& Hammond, 2013) \\
\hline 12 & Celery & $0-30$ & (Lott \& Hammond, 2013) \\
\hline 13 & Eggplant & $0-45$ & (Lott \& Hammond, 2013) \\
\hline 14 & Cabbage & $0-45$ & (Lott \& Hammond, 2013) \\
\hline
\end{tabular}




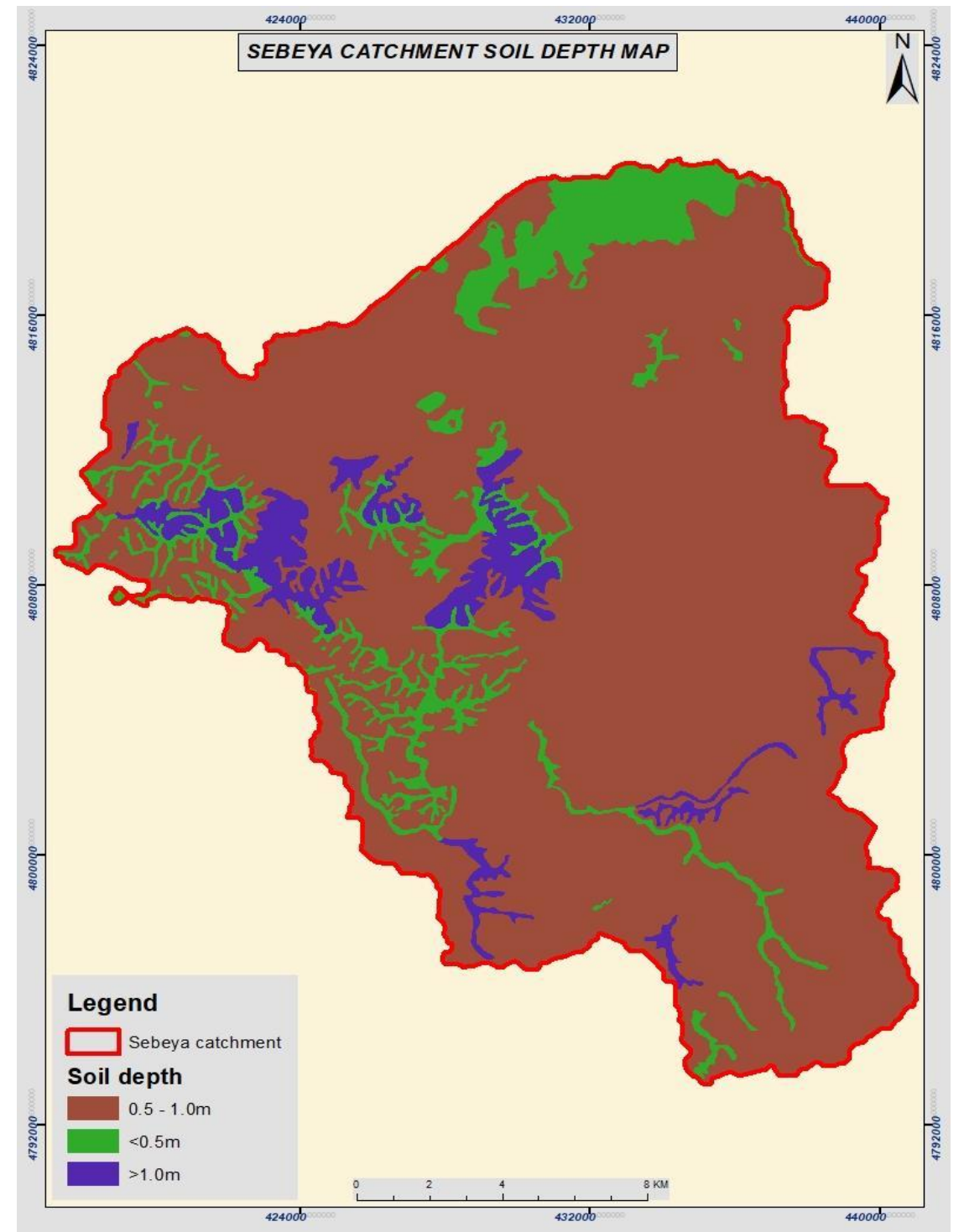

\section{Figure 3. Sebeya catchment soil depth map}

\subsubsection{Proposal of BMPs for soil erosion control in Sebeya catchment}

Terraces are more favorable in agricultural land with steep slopes ranging from $16 \%$ to $40 \%$ while progressive terraces and contour bunds are suited to flat areas of slopes less than 16\% (IWRM, 2016). Erosion control measures in Sebeya catchment were proposed based on land slope range (MoE, 2018a). The table8 presents details and requirements on how various BMPs for soil erosion control can be effectively implemented in Sebeya catchment according to slope range. By combination of various physical measures, it is recommended that biological measures such as planting trees and grasses as well as lime and compost applications can be undertaken. 
Table 8. Proposed BMPs for soil erosion control in Sebeya catchment: adapted from (IWRM, 2016)

\begin{tabular}{|c|c|c|c|}
\hline $\begin{array}{l}\text { Soil depth } \\
\text { Land slope }\end{array}$ & $1:(>1 \mathrm{~m})$ & $2:(0.5-1 \mathrm{~m})$ & $3:(<0.5 \mathrm{~m})$ \\
\hline$(0-6 \%)$ & $\begin{array}{l}\text { Agroforestry }+ \\
\text { Contour ploughing }+ \\
\text { Mulching }+ \text { Grass } \\
\text { strip }\end{array}$ & $\begin{array}{l}\text { Agroforestry }+ \\
\text { Contour ploughing }+ \\
\text { Mulching }+ \text { Grass } \\
\text { strip }\end{array}$ & $\begin{array}{l}\text { Agroforestry }+ \\
\text { Contour ploughing }+ \\
\text { Mulching }+ \text { Grass } \\
\text { strip }\end{array}$ \\
\hline$(6-16 \%)$ & $\begin{array}{l}\text { Progressive terraces } \\
+\quad \text { Mulching or } \\
\text { Contour bund }+ \\
\text { Mulching }\end{array}$ & $\begin{array}{l}\text { Progressive terraces }+ \\
\text { Mulching or Contour } \\
\text { bund }+ \text { Mulching }\end{array}$ & $\begin{array}{l}\text { Progressive terraces } \\
+\quad \text { Mulching or } \\
\text { Contour bund } \\
\text { Mulching }\end{array}$ \\
\hline$(16-40 \%)$ & Bench terraces & Bench terraces & $\begin{array}{l}\text { Progressive terraces } \\
\text { or Contour bund }\end{array}$ \\
\hline$(40-60 \%)$ & Bench terraces & Bench terraces & Afforestation \\
\hline$(>60 \%)$ & Afforestation & Afforestation & Afforestation \\
\hline
\end{tabular}

\subsection{Existing Constraints for Implementation of Soil Erosion Measures in Sebeya Catchment}

\subsubsection{Social constraints}

Farmers are not motivated to provide enough space from their fields to waterways and they do not want to adopt hard BMPs of erosion control such as terraces and anti-erosive ditches. The reason for farmers to refuse adoption of terracing is that for shallow soil, terraces expose sub soil which is infertile (Kituku et al., 2011). The table9 shows the proportions of socio-constraints.

Table 9. Social constraints on implementing soil protection measures in Sebeya catchment

\begin{tabular}{|c|c|c|c|}
\hline No. & $\begin{array}{l}\text { Limiting social factors on soil protection measures } \\
\text { implementation }\end{array}$ & Number & $\begin{array}{l}\text { Percentage } \\
(\%)\end{array}$ \\
\hline 1 & $\begin{array}{l}\text { Farmers are not motivated to provide enough space from } \\
\text { their fields to waterways }\end{array}$ & 16 & 21.43 \\
\hline 2 & $\begin{array}{l}\text { Farmers do not want to adopt mechanical measures of } \\
\text { soil erosion like radical terraces }\end{array}$ & 18 & 24 \\
\hline 3 & $\begin{array}{l}\text { Few farmers access to socio-medias on soil erosion } \\
\text { control measures }\end{array}$ & 12 & 16 \\
\hline 4 & Farmers resist to vote for crop rotation & 9 & 12 \\
\hline 5 & Low educational level and trainability & 20 & 28.57 \\
\hline Total & & 75 & 100 \\
\hline
\end{tabular}




\subsubsection{Economic constraints}

As shown in table10, the number of farmers that access microfinance credit is estimated at $24 \%$. Some farmers $(21.33 \%)$ do not have sufficient energy or income to adopt hard soil erosion control measures like: radical terraces and anti-erosive ditches. This study revealed that challenges faced in adopting soil protection measures are poverty which is in agreement with (Barbier, 1990) who reported that lack of money is the main factor limiting the adoption of soil water conservation (SWC) techniques in Java. (Bidogeza et al., 2007) reported that most of SWC techniques are costly and there are hence less adopted in Rwanda by poor resources farmers.

Table 10. Economic constraints on implementation of soil protection measures in Sebeya catchment

\begin{tabular}{llll}
\hline No. & $\begin{array}{l}\text { Limiting economic factors on soil protection measures } \\
\text { implementation }\end{array}$ & Number & $\begin{array}{l}\text { Percentage } \\
\text { \% }\end{array}$ \\
\hline 1 & Few farmers access to microfinance credit & 18 & 24 \\
2 & $\begin{array}{l}\text { Few farmers access to inputs (inorganic fertilizer) } \\
3\end{array} \quad \begin{array}{l}\text { Some farmers do not have sufficient energy or income to } \\
\text { adopt hard soil erosion control measure like: radical }\end{array}$ & 16 \\
$\quad \begin{array}{l}\text { terraces and anti-erosive ditches } \\
4\end{array}$ & 29 & \\
Others & 75 & 41.67 \\
\hline Total & & 100 \\
\hline
\end{tabular}

\subsubsection{Institution constraints}

The table11 shows that the farmers support in getting pesticides by Government and Non-Government institutions are limited to $29.33 \%$. Seeds and fertilizers reach farmers over time $(22.66 \%)$ and this research is highlighting lack of farmers trainings in soil conservation measures at $18.66 \%$. This shows that the supports from the Government and Non-Government institutions are not sufficient for implementing the soil protection measures in Sebeya catchment. (Bizoza, 2011) confirmed that sharing knowledge among farmers through trainings could enhance adoption of soil protection measures in Rwanda.

Table 11. Institutional constraints on the implementation of soil protection measures in Sebeya catchment.

\begin{tabular}{llll}
\hline No. & $\begin{array}{l}\text { Limiting institutional factors on soil protection } \\
\text { measures implementation }\end{array}$ & $\begin{array}{l}\text { Number } \\
\%\end{array}$ \\
\hline 1 & Pesticides from Government and Non-Government \\
& institutions are to support a limited number of farmers & 22 & 29.33 \\
2 & Seeds and fertilizers reach farmers over time & 17 & 22.66
\end{tabular}




\begin{tabular}{llll}
3 & Lack of motivation to farmers who are applying well & & \\
& the BMPs in their farming system & 10 & 13.33 \\
4 & Lack of farmers trainings in soil conservation measures & 14 & 18.66 \\
5 & Other(s) & 12 & 16.02 \\
\hline & Total & $\mathbf{7 5}$ & $\mathbf{1 0 0}$
\end{tabular}

\subsubsection{Government responsibility in improving farming system in Sebeya catchment}

The table12 indicates farmers views on what can be the Government responsibility in improving farming system in Sebeya catchment. The majority of farmers suggest trainings and mobilization of a specialized technical team to assist them in implementing soil conservation measures and to generalize the application of fertilizers in the whole catchment. Also, the Government should facilitate farmers access to microfinance credit. These results are not far from those of (Traorè, 1998) who said that farmer's knowledge about a practice cannot allow its adoption unless they understand its expected costs and benefits. Furthermore, (Solomon, 2016) indicated that when farmers did not have more information about a Soil Conservation Measure, they cannot be expected to adopt it.

\section{Table 12. Government responsibility in improving farming system in Sebeya catchment}

\begin{tabular}{|c|c|c|c|}
\hline No. & Government duty & $\begin{array}{l}\text { Numbe } \\
\mathbf{r}\end{array}$ & $\begin{array}{l}\text { Percentage } \\
(\%)\end{array}$ \\
\hline 1 & $\begin{array}{l}\text { Trainings and mobilization of a specialized technical team to } \\
\text { assist in implementation of soil conservation measures }\end{array}$ & 17 & 22.67 \\
\hline 2 & $\begin{array}{l}\text { Sensitization of farmers on the benefits of the land use } \\
\text { consolidation and the selection of suitable cover crops which } \\
\text { will minimize soil erosion }\end{array}$ & 5 & 6.67 \\
\hline 3 & $\begin{array}{l}\text { To generalize the application of fertilizers in the whole } \\
\text { catchment }\end{array}$ & 11 & 14.67 \\
\hline 4 & To facilitate farmers access to microfinance credit & 10 & 13.33 \\
\hline 5 & Others way & 26 & 34.67 \\
\hline \multicolumn{2}{|c|}{ Total } & 75 & 100 \\
\hline
\end{tabular}

\section{CONCLUSION AND RECOMMANDATIONS}

Research findings of this study highlighted the suitability and performance of various erosion control measures for agriculture fields, slope and riverbank stabilization. Soil erosion control measures including agro-forestry, terraces, mulching, tree planting, contour bunds, vegetative measures for slopes and buffer zones, check dams, riverbanks stabilization were proposed in Sebeya catchment and recommended to be improved or implemented. This research finally recommended Government 
https://doi.org/10.4314/rjeste.v3i2.4

agencies and NGOs to be extensively involved in soil erosion management and to generalize supports to all farmers in Sebeya catchment.

\section{ACKNOWLEDGEMENTS}

The authors are grateful to the University of Rwanda (UR) for its support and wish to acknowledge the support of UR SWEDEN PhD PROGRAM in sponsoring this research. We cannot fail to commend and appreciate the work of various authors used for the present study.

\section{REFERENCES}

Admiraal, D. M. (2007). Streambank stabilization using traditional and bioengineering methods: A literature review. [Report]. University of Nebraska. Lincoln, UK.

Ampofo, E. A., Muni, R. K., \& Bonsu, M. (2002). Estimation of soil losses within plots as affected by different agricultural land management. Hydrological Sciences, 47(6), 957-967.

Bai, J., Shengtian, Y., Yichi, Z., Xiaoyan, L., \& Yabing, G. (2019). Assessing the impact of terraces and vegetation on runoff and sediment routing using the time-area method in the chinese Loess Plateau. Water, 803(11), 1-20, doi:10.3390/w11040803.

Bakker, M. M., Govers, G., Jones, R. A., \& Rounsevell, M. D. A. (2007). The effect of soil erosion on Europe's crop yields. Ecosystems, 10, 1209-1219.

Bakoji, Y. (2017). Soil erosion: Farmers perception and conservation measures in the Northern part of Taraba state. [PhD thesis]. University of Malaya Kuala Lumpur. Taraba state, Nigeria.

Barbier, E. (1990). The farm-level economics of soil conservation: the uplands of Java. Land economics, 66(2), 199-211.

Barsher, L., Moores, J., \& Mclean, G. (2016). Scientific basis for erosion and sediment control practices in New Zealand. Landcare Research. Richmond, New Zealand.

Bidogeza, J., Berentsena, P. B., De Graaff, J. \& Oude Lansinka, A. G. (2007). Multivariate typology of farm households based on socio-economic characteristics explaining adoption of new technology in Rwanda. AAAE Ghana Conference Proceedings, 175-281.

Birhanu, Z., Ramadjita, T., Bougouna, S., Fourter, N., \& Suhan, P. (2014). Assessment of contour bunding technology for improved land and water management in Mali. [Report]. International Crops Research Institute for the Semi-Arid Tropics. Telangana, India.

Bizoza, A. (2011). Farmers, institutions and land conservation. [PhD thesis]. Wegeningen University. Wegeningen, Dutch.

Christoffel, D. B., Rattan, L., Kieth, W., \& Vince, B. (2000). Impacts of soil erosion on crop yields in North America . Academic Press. Washington DC, USA.

Dooley, J. H., Lanning, D. N., Burks, J. E., Randy, B., \& Foltz, R. B. (2005). Field performance of longstrand wood erosion control mulch and agricultural straw under natural rainfall events. [Report]. University of Washington. Washington DC, USA.

FAO (1983). Fertilizer use under multiple cropping system. Food and Agriculture Organization of the United Nations. Rome, Italy.

Gali, R. K., Soupir, M. L., Kaleita, A. L., \& Daggupati, P. (2015). Identifying potential locations for grassed waterways using terrain attributes and precision conservation technologies. American Society of Agricultural and Biological Engineers, 58(5), 1231-1239.

doi:10.13031?trans.58.10995. 
https://doi.org/10.4314/rjeste.v3i2.4

Gray, D. H., \& Leiser, A. T. (1982). Biotechnical slope protection and erosion control. Krieger Publishing Company. Makabar, Florida.

IWRM (2016). Feasibility study and detail design of the early implementation project on Sebeya catchment. [Report]. Ministry of Natural Resources. Kigali, Rwanda.

IWRM (2017). Sebeya catchment plan 2017-2023. [Report]. Ministry of Natural Resources. Kigali, Rwanda.

IWRM (2018). Sebeya catchment plan 2018-2024. [Report]. Ministry of Natural Resources. Kigali, Rwanda.

Karamage, F., Zhang, C., Ndayisaba, F., Shao, H., Kayiranga, A., Fang, X., Tian, G. (2016). Extent of cropland and related soil erosion risk in Rwanda. Sustainability, 608(8), 1-19, doi:10.3390/su8070609

Kituku, M. G., Muwanga, A., Poesen, J., \& Deckers, J. A. (2011). Farmer's perception on landslide occurrences in Bududa District, Eastern Uganda. [Report]. National Environmental Management Authority. Kampal, Uganda.

Liu, X., Zhang, X., Wang, Y., Sui, Y., Zhang, S., Herbert, S., \& Ding, G. (2010). Soil degradation: a problem threatening the sustainable development of agriculture in Northeast China. Plant Soil Environment, 56(2), 87-97.

Lott, E, D., \& Hammond, V, E. (2013). Vegetable and Fruit Production. University of Nebraska. Lincoln, UK.

MoE (2018a). Mapping of erosion in Rwanda and guidelines for erosion control. [Report]. Ministry of Environment. Kigali, Rwanda.

MoE (2018b). Sebeya catchment management plan (2018-2024). [Report]. Ministry of Environment. Kigali, Rwanda.

Munyaneza, O., Majoro, F., Mutake, S., \& Hagenimana, E. (2015). Performance evaluation of sediment basins: Case study of keya hydropower plant in Rwanda. Journal of Water Resource and Protection, 7, 1387-1398.

Nedunchezhiyan, M., Byju, G., \& Jata, K. S. (2012). Sweet potato agronomy. Fruit, Vegetable and Cereal Science and Biotechnology, 6(1), 1-10.

NISR. (2014). Rwanda demographic and health survey 2014-15. [Report]. National Institute of Statistics of Rwanda. Kigali, Rwanda.

Onu, F. M., \& Mohammed, A. (2014). Competency improvement needs of farmers in soil erosion prevention and control for enhancing crop production: Case study of Kogi State, Nigeria. Agricultural Sciences, 5, 958-963.

Ouyang, D., Bartholic, J., \& Selegean, J. (2005). Assessing sediment loading from agricultural croplands in Great Lakes Basin. The Journal of American Science, 1(2), 14-21.

Peng, C., Yonggang, G., \& Yongming, L. (2011). Soil erosion and sediment control effects in the Three Gorges Reservoir Region, China. Journal of Resources and Ecology, 2(4), 289-297.

Plessis, J. (2003). Maize production. [Report]. Department of Agriculture. Pretoria, South Africa.

RNRA. (2012). Consultancy services for development of Rwanda national water resources master plan. [Report]. Rwanda Natural Resources Authority. Kigali, Rwanda.

Sadeeka, L., Kumar, L., \& Sandamali, J. (2019). Assessment of potential land suitability for tea in Sri Lanka Using a GIS-based multi-criteria approach. Agriculture, 48(9), 1-26.

Shahin, M. M. (1993). An overview of reservoir sedimentation in some African river basins. Sediment Problems: Strategies for Monitoring, Prediction and Control (Proceedings of the Yokohama Symposium), 217, 93-100. 
Solomon, B. (2016). Assessment of factors that determine farmer's adoption behaviour of soil and water conservation practices in Libo Kemkem Woreda. [MSc thesis]. University of Addis Ababa University. Addis Ababa, Ethiopia.

Traorè, R. A. (1998). On-farm adoption of conservation practices: The role of farm and farm characteristics, perception and health hazards. Land Economics, 74(1), 114-127.

WHO (2011). Guidelines for drinking-water quality ( $\left.{ }^{\text {th }} e d\right)$. World Health Organization Press. Geneva, Switzerland.

Young, A. (1989). Agroforestry for soil conservation. CAB International. Wallingford, UK. 